\title{
Strategies to Increase Satisfaction to Establish Student Behavior by Creating Reputation, Physical Evidence and Academic Information Systems in Higher Education in Central Java Region
}

Siti Fatonah; I Gusti Putu Diva Awatara

STIE Adi Unggul Bhirawa, Surakarta, Indonesia

http://dx.doi.org/10.18415/ijmmu.v6i5.1050

\begin{abstract}
This study aims to determine the effect of Reputation, Physical Evidence and Academic Information Systems on satisfaction and its impact on student loyalty in shaping student behavior in Private Colleges in Central Java. Sampling in this study using Random sampling technique. The number of samples taken in this study were 125 respondents who were students of Private Colleges in Central Java. The analytical tool used is the research instrument test, linearity test, path analysis and regression with $\mathrm{t}$ test, $\mathrm{F}$ test and $\mathrm{R} 2$ test. The t-test results show that Reputation, Physical Evidence and Academic Information Systems have a positive effect on student satisfaction. And Reputation, and satisfaction have a positive effect on loyalty in shaping student behavior. While the Academic Information System has a negative effect on loyalty in shaping student behavior. Direct and indirect effect results can be concluded that the satisfaction variable as an intervening variable of reputation is ineffective, and more effective reputation directly influences the behavior of students of Central Java Region Private Colleges. The direct and indirect influence can be concluded that the satisfaction variable as the intervening variable of the Academic Information System is effective, because the indirect influence through student satisfaction is greater. Whereas for the most dominant and most effective path to improve student behavior to be loyal to Private Colleges is a reputation / image path to student loyalty directly in shaping student behavior, because it has the highest regression coefficient value. Whereas to increase satisfaction is the most effective through increasing / improving physical evidence.
\end{abstract}

Keywords: Reputation; Physical Evidence; Academic Information System; Student Satisfaction; Behavior

\section{Introduction}

Higher education is an institution that plays an important role in the process of human resources development. Through the educational programs of each private college which is well controlled, hopefully can produce qualified graduates. Changes in the increasingly higher educational world, requiring private colleges to respond to changes occurring, problems faced by Private Colleges today are the way private colleges attract students and Maintain that the private colleges can survive and thrive. The 
development of the need for higher education eventually opened the opportunity for the private sector to participate in the efforts to conduct education. The college is divided into two, namely State Colleges (PTN) and Private Colleges (PTS). PTN is an educational institution organized by the Government, while the PTS is an educational institution organized by private parties.

The management of PTS is conducted by the community with laws and regulations in Indonesia. In carrying out its activities, the PTS is supervised and guided by Private College Coordination (KOPERTIS). Private Colleges are currently being faced with hyper competition, where Private Colleges (PTS) not only compete with others, but also compete with State Colleges (PTN). This is due to the inequality that occurred in the elections of the Private Colleges, where prospective students will be more likely to choose the public Private Colleges in comparison with Private Colleges. Whereas along with the development of the epoch, Private Colleges have begun to be accounted for in the field of employment, as well as having the same standard of education costs and quality that is not inferior to the public universities of private.

The ongoing Hyper competition demands every private private college to adopt strategies that are used in non-educational industries. Competitive advantage is one of the main capital to attract students. In order to win the competition, of course every private private college should carry out its operational activities with good quality-oriented and must know what the students are required and want. The growth of private colleges makes students have many alternatives to choose from. Taylor \& Massy considers that the number of students to be lifeblood for each private college therefore needs to be monitored seriously because it will also affect the source of income and other academic life (Riswono, $2010: 2$ ).

So, it can be concluded that the service to the students is the most important thing that can impact the satisfaction of students, which in turn also foster loyalty and shaping behavior of students in Private Colleges that They choose. From the satisfaction and loyalty of such students the party of Private Colleges earn income. Facing very sharp competition in the world of education and student expectations, the Private Colleges in the Central Java region must be able to fulfill all the needs and wishes of students who eventually create satisfaction, because one aspect The success of an educational institution in winning the competition is with adequate infrastructure and building and has the appropriate activities plan and use a viable technology system for each product or service Provided, it can be done if the service provides maximum support for products and services that meet the needs and tastes of students. According to Nina Rahmayanty (2010:6) It is believed that the main key to win the competition one of them is to provide value and satisfaction through delivery of quality products or services, the student loyalty should be a major factor that must By Private Colleges in the Central Java region to defend students from year to year. Private Colleges in the region of Central Java will be able to succeed and compete in the market if the level of satisfaction of students in the use of products or services and services is high enough.

In this case, the quality of products or services also contains the meaning of reputation. Conversely, if a student in this case students and the wider community have a positive perception of the institution's reputation, then the public belief in Private Colleges will also increase. Furthermore, this will affect the loyalty of students and the public to continue to use the services of Private Colleges and courses in the future.

Student satisfaction is very much determined by the quality of the service that students want, so that the private college, in this case as an educational service provider should emphasize on the provision of quality services to Students and the wider public. One of the factors assessed through reputation in private colleges is physical evidence. 
In addition to the increase in reputation, private colleges also need to improve the reputation of private colleges. Reputation is a goal as well as achievement to be achieved for the world public relations. The role and function of public relations in building a reputation can be realized if there are strategies arranged and planned in a mature. Strategy here can be an alternative chosen to be taken to achieve public relations objectives in the framework of a public relations plan. A good Private Colleges reputation will have an impact on improving the quality and development of Private Colleges, such as: Increased student satisfaction, increasing student numbers, and others. Conversely, if the reputation of a private college is known to be not good or bad, it can be a problem for Private Colleges and may cause the private colleges to lose their market, or in other words Reduction of student confidence in the Private Colleges and switching to other private colleges. Next according to Casey (2006:8) "Reputation is about to become more integral to the bottom line thanks to the next generation of consumers". Thus, it can be attributed that reputation is an important factor for private colleges to acquire and maintain Sustanablenya. A good reputation will avoid students to migrate to private colleges of competitors, while poor reputations could result in private colleges becoming increasingly stunted.

In addition to the quality of service in the form of physical evidence and reputation, amid rapid technological advancement and the need for fast and precise information an institution of Private Colleges is required to utilize the support of information systems based on Good technology, so that all activities implemented can run effectively and efficiently. With such quality of education and service can increase and competitive advantage will be achieved. Private Colleges in the Central Java region itself has utilized a technology-based information system used for administrative activities known as the name of the academic Information System (SIAKAD). In the academic information system, students can conduct academic transactions online, see Academic calendar, curriculum info, lecture schedule, exam schedule, student data, grades, study cards (KHS) and study plan cards (KRS). All that can be done online without having students come to the campus.

But as we know every progress or development there are certain constraints such as the utilization that is still lacking because some students consider it as something complicated or difficult. The information system is built as a performance support facility in an institution that is intended to facilitate the task of user so that the saving of time, cost, and resources is achieved. The academic information system is a special system for the purpose of managing academic data with the application of computer technology both ' hardware ' and ' software '. The meaning of ' hardware ' is hardware that is equipment such as PC Computer, Printer, CD ROM, Hardisk, and so on. Medium Software is a computer program that enables the hardware that is made specifically for the purposes of management of academic data, (Jogiyanto 2010). Computer Hardware to be used can be purchased on the market, in places of computer sales. Moderate software, must be made with certain programming techniques.

The satisfaction of the service and users of an academic information system is one of the factors or measure of success for each development and implementation of services and academic information systems in a private institution/college. Good quality of service and academic information system can be seen based on the perspective/perception of service users and information systems that is a thorough assessment of the excellence of a service. Therefore, the satisfaction measurement of the services and users of the academic information system provided must always be undertaken. It aims to know and plan better strategies in the future and to improve the quality of services and academic information systems in order to fulfill students ' wishes and needs.

Keep in mind that expectations evolve over time as more and more information is received and the more experience it grows. In turn all this will affect the achievement of a result that is loyalty. Students are the assets of private colleges or institutions, so that the private colleges must maintain and maintain their students. According to Kotler and Keller (2009), loyalty or loyalty is defined as a strongheld commitment to buying or resubscribing to certain products or services in the future. Loyalty will be 
the key to success not only on the short term but also to have an ongoing competitive edge, even if there is a potential impact on the situation and marketing efforts that could potentially cause behavior change.

Based on several descriptions above, research is done to know the factors that affect the loyalty of private college students in Central Java region. In this study selected the variable reputation, physical evidence and academic information system with satisfaction as a intervening variable that affects loyalty in shaping the behavior of private college students in Central Java region, because It is suspected that these variables have a significant influence on the loyalty of private college students in Central Java region.. And through such research, researchers took the title "Strategies to increase satisfaction to shape student behaviour by creating reputation, physical evidence and academic information systems at Private Colleges in the Central Java region".

\section{Method}

Samples are part of the number of characteristics owned by the population. When large populations and researchers are unlikely to learn all that is in the population, for example due to limited funds, energy and time, researchers may use samples taken from the population. According to Arikunto (2010:131) The samples were partially or representatives of the population being studied, the way the sampling was conducted with propotional random sampling. The number of samples determined the number of student PTS by population. Based on the data and theory, the number of samples in this study was sampled 125 students at Private Colleges in the Central Java region. Then the researcher will take the sample as many number of students present at Private Colleges in the region of Central Java is as much as 125 people.. This research uses analysis tools in the form of validity test, reliability test, linierity test, pathway analysis, multiple linear regression analysis, $\mathrm{T}$ test, $\mathrm{F}$ test and coefficient of determination.

A regression analysis of pathways is, a pathway analysis is a direct development of multiple regression forms with the aim to provide an estimate of the level of interest (magnitude) and the signification (significance) cause of hypothetical causation A set of variables.

Causality relationship will be used for pathway analysis and intervening. In this study the satisfaction variables were placed as intervening variables for the variable reputation, physical evidence and academic identification systems against student behavior.

Multiple linear regression analyses are used to analyze the effect of some free variables or independent variables (X) against one non-free variable or variable dependent (Y) as follows:

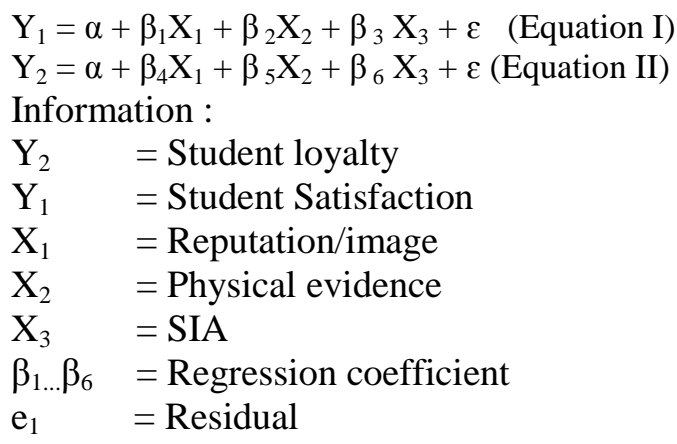




\section{Research Results}

Based on the results of track analysis can be obtained:

Equation 1 is:

$\mathrm{Y}_{1}=0,176 \mathrm{X}_{1}+0,259 * * \mathrm{X}_{2}+0,060 \mathrm{X}_{3}+\epsilon$

Equation 2 is:

$\mathrm{Y}_{2}=0,141 \mathrm{X}_{1}-0,008 \mathrm{X}_{3}+0,459 \mathrm{Y}_{1}+\epsilon$

\section{Model of Analysis Results:}

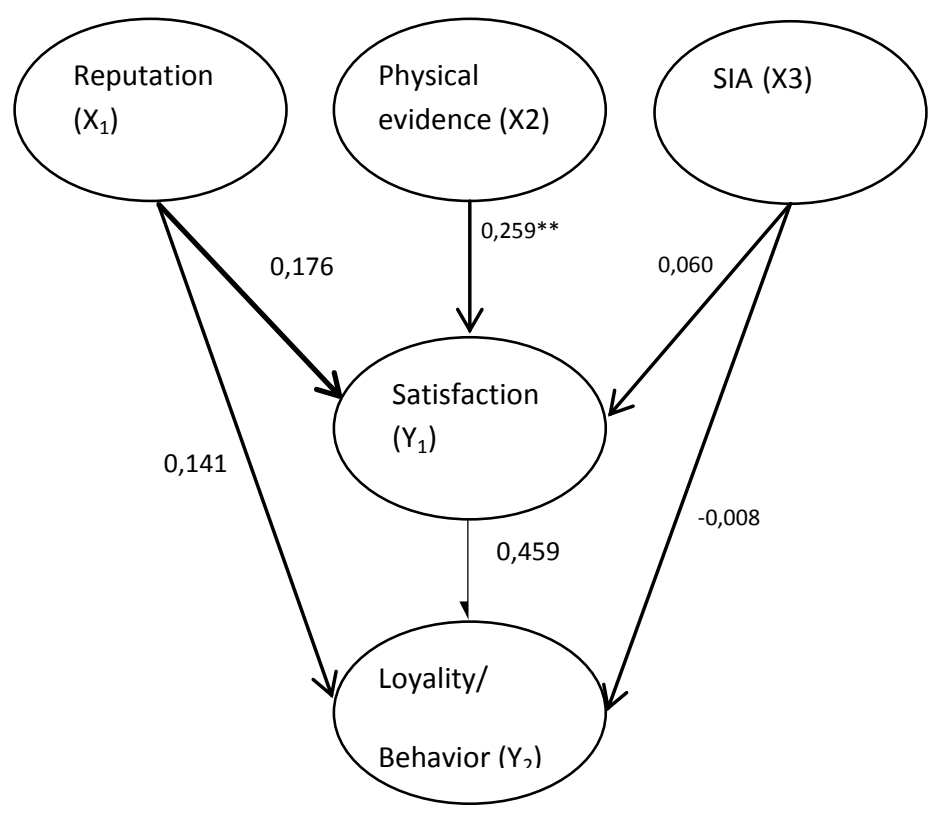

Picture 1. Path Diagram

\section{Results}

Results of processed data obtained direct and indirect influence as follows:

\begin{tabular}{|l|l|l|}
\hline \multicolumn{1}{|c|}{ Explanation } & \multicolumn{1}{|c|}{$\beta$} & Sig \\
\hline $\mathrm{X}_{1} \rightarrow \mathrm{Y}_{1}$ & 0,176 & \\
\hline $\mathrm{X}_{2} \rightarrow \mathrm{Y}_{1}$ & $0,256^{* *}$ & \\
\hline $\mathrm{X}_{3} \rightarrow \mathrm{Y}_{1}$ & 0,060 & \\
\hline $\mathrm{X}_{1} \rightarrow \mathrm{Y}_{2}$ & 0,141 & \\
\hline $\mathrm{X}_{3} \rightarrow \mathrm{Y}_{2}$ & $-0,008$ & \\
\hline $\mathrm{X}_{1} \rightarrow \mathrm{Y}_{1} \rightarrow \mathrm{Y}_{2}$ & $=0,176 \times 0,459=0,081$ \\
\hline $\mathrm{X}_{3} \rightarrow \mathrm{Y}_{1} \rightarrow \mathrm{Y}_{2}$ & $=0,060 \times 0,459=0,004$ \\
\hline
\end{tabular}




\section{Discussion}

\section{Reputation influence on student behaviour through student satisfaction}

From the analysis of this line indicates that the use of the student satisfaction intervening variables in order to increase student behavior, for the variable reputation shows ineffective, due to the direct influence of quality of service to the behaviour Students produce greater influence than through the student satisfaction intervening variable $(0.141>0.081)$.

In principle, the quality of services is centered on fulfilling the wishes and needs of students and the accuracy of delivery to offset student expectations. This illustrates that reputation is the ability of a private college in providing quality service to its students. Good service is the overall impression of the students on the inferiority/superiority of the organization and services offered, so that the reputation is the level of excellence that is expected to shape the student behavior is more loyal in Private colleges.

Therefore, there should be efforts to be undertaken for the evaluation of the reputation by maintaining:

a. Private Colleges in Central Java are known to have professional teachers in their environment

b. Private Colleges in Central Java are known to have a complete health course

c. Graduates of Private Colleges in Central Java are known to easily obtain jobs after graduation

d. Private Colleges in Central Java are well known as good campuses in student's eyes

e. Private Colleges in Central Java is known as a campus at an affordable cost by the society

\section{Influence of academic Information System (SIA) on student behaviour through student satisfaction}

The use of student satisfaction intervening variables in order to increase student behavior, for the variable of academic information systems (SIA) effective, because the direct influence of SIA on student behavior resulted in a lesser influence than Through the student satisfaction intervening variable, so that the academic information System (SIA) can improve student behaviour by the student satisfaction $(-0.008<0.004)$.

Therefore, to improve the behavior of student students then private colleges in the Central Java region adequately maintain the academic information System (SIA) by:

a. SIA is used greatly saving student time.

b. SIA used to facilitate student academic activities

c. Operation of SIA used easily

d. SIA is easily accessible anywhere

e. Information presented complete and easy to read

\section{Effect of physical evidence on student satisfaction}

The use of variable student satisfaction in order to increase student behaviour, for variable physical evidence generates influence through student satisfaction variables. This means that in order to increase the student satisfaction should be directly on the physical proof variable.

The step is to improve physical evidence by maintaining: 
a. Improved collection of references in Private Colleges library in Central Java complete and adequate

b. Private colleges in Central Java improve the extensive parking facilities to students

c. Private colleges in Central Java pay attention to hygiene issues in campus environment

d. Improve the comfort of classrooms where the student process performs activities very comfortably.

e. Provide multipurpose building or representative hall to hold student activities

\section{Conclusion}

Based on the results of analysis and discussion, then it can be drawn conclusions as follows:

1) Reputation has a positive effect on student satisfaction. This means that if a reputation improves students ' satisfaction better.

2) Physical evidence has a positive effect on student satisfaction. This means the better the physical evidence then the higher the student satisfaction.

3) The Academic Information System (SIA) positively affects student satisfaction. This means the better the Academic Information System (SIA) then the higher the satisfaction of students

4) Reputation has a positive effect on student behaviour. This means that if reputation improves the student's behavior is increasingly loyal.

5) The Academic Information System (SIA) negatively affects student behavior. This means that if the academic information System (SIA) is getting better then the student behavior is decreasing to be loyal.

6) Satisfaction has positive effect on student behavior. This means the better the satisfaction the better the student behaviour to be loyal.

7) The direct and indirect influence above, can be concluded that the variable satisfaction as a variable intervening reputation is ineffective, and more effective reputation directly affects the student behavior of Private Colleges Central Java region.

8) The direct and indirect influence above, can be concluded that the satisfaction variable as a variable intervening academic information System (SIA) is effective, due to indirect influence through greater student satisfaction. .

9) And while the physical evidence variable is more effective through satisfaction. From the analysis of visible pathways that to increase satisfaction most effectively through the strengthening of physical evidence.

Based on the above conclusions, the suggestions that can be given include:

\section{Influence of reputation on student behaviour through student satisfaction}

From the analysis of this line indicates that the use of the student satisfaction intervening variables in order to increase student behavior, for the variable reputation shows ineffective, due to the direct influence of quality of service to the behaviour Students produce greater influence than through the student satisfaction intervening variable.

In principle the quality of service centered on the fulfillment efforts and needs of students and the accuracy of delivery to compensate students expectations. This illustrates that reputation is the ability of a private college in providing quality service to its students. Good service is the overall impression of the students on the inferiority/superiority of the organization and services offered, so that the reputation is the level of excellence that is expected to shape the student behavior is more loyal in Private colleges. 
To influence the students ' behaviour to be the most efficient by improving the reputation of PTS Secarta directly as follows:

a. Private Colleges enhance professional lecturers/educators in the PTS environment

b. The Private Colleges should improve the opening of a complete course and the interest of the community.

c. The private college became the fusermadiance of the graduates with a job search agency,

d. Private colleges improve image images in the eyes of people/students

e. Private Colleges should pay attention to students ' ability in financing the study.

\section{Influence of academic Information System (SIA) on student conduct through student satisfaction}

The use of student satisfaction intervening variables in order to increase student behavior, for the variable of academic information systems (SIA) effective, due to the direct influence of the academic Information System (SIA) on student behaviour resulted Less influence than through the student satisfaction intervening variable, so that the academic information System (SIA) can improve student behaviour through student satisfaction.

Therefore, the use of SIA should be able to make the students more profitable for example by:
a. SIA used greatly saves me time
b. SIA used to facilitate student academic activities
c. Operation of SIA used easily
d. SIA is easily accessible anywhere
e. Information presented complete and easy to read

\section{Influence of physical evidence against the satisfaction of students}

The use of variable student satisfaction in order to increase student behaviour, for variable physical evidence generates influence through student satisfaction variables. This means that in order to increase the student satisfaction should be directly on the physical proof variable.

The step is to improve physical evidence by improving:

a. Collection of references in the library of private high school colleges in Central Java complete and adequate

b. Private Higher School facilities in Central Java provide a large parking space for students

c. Private colleges in Central Java increase the attention of hygiene problems in campus environments

d. Classrooms where student processes perform convenience activities.

e. The Multipurpose building attention or representative Hall to hold student activities.

\section{Increased satisfaction of students should be considered, by adding satisfaction to physical evidence related to the quality of output, among others:}
a. Add the reference to the library
b. Improve information technology systems,
c. Increase the comfort of campus circled
d. Attention to class needs in the comfort of the learning process
e. Taking into account the places where non-learning activities are needed
f. Always keep the cleanliness and comfort around the campus 


\section{References}

Albert, Weldison, 2007. Mahasiswa Bank Dalam Likuidasi. Hasil Survei. Econit Advisory Group dalam Swasembada. Desember. Jakarta.

Alma, Buchari, 2000. Manajemen Pemasaran dan Pemasaran Jasa. Alfabeta, Bandung.

Anderson, James C., D.C. Jain, and Pradeep K. Chintagunta, 2007. Customer Value.

Assessment In Business To Business Markets: A State of Practice Study. Journal of Business To Business Marketing, Vol. 1, US.

Arief, Sritua, 2003. Metodologi Penelitian Ekonomi, Cetakan Pertama. Penerbit Universitas Indonesia. Jakarta.

Arikunto, Suharsimo, 2003. Dasar-Dasar Evaluasi Pendidikan, Penerbit Rineka Cipta, Jakarta.

Assael, Henry, 2002. Customer Behaviour and Marketing. Gourth Edition. PWS-Kent Publishing company. Boston-USA.

Astuti, 2002, Pengaruh Nilai Mahasiswa, Reputasi, Relationship, Produk terhadap kepuasan dan Transaksi bank di Bank Indonesia wilayah kerja Malang, thesis, Unair.

Azwar, Saifudin, 2005. Basic Econometrics, $3^{\text {rd }}$ ed. McGraw-Hill International. New York.

Bitner, Mary Jo, 2000. Building Service Relationship: It's All About Promises. Journal Of The Academy Of Marketing Science. Vol. 23, No. 4, Miami.

Cronin, J. Joseph dan Steven A. Taylor, 2002, Measuring Service Quality: A Reexamination and Extention, Journal of Marketing, Vol. 56, 55-68.

Measurement of Service Quality, Journal of Marketing, Vol. 58, 125-131.

Elliott, 2003, three customer values are key to market success, The Journal of Retail Banking Service.

Ferdinand, Augusty, (2000), Struktural Equation Modeling, BP Undip Semarang.

Fornell, C., 2006, A National Customer Satisfaction Barometer: The Swedish Experience, Journal of Marketing, 56, 6-21.

Frieder, Larry A., Gregor, William T., 2006. Bank Valuations : Meeting Customer.

Investor Needs (Part I). Bankers Magazine. Vol. 179. July/August. UMI-US.

. 2006. Bank Valuations: Meeting Customer.

Investor Needs (Part II). bankers Magazine. Vol. 179. July/August. UMI-US.

Garvin, 2007, Competing on quality, Harvard Business Review,65. 
Gale, Bradley T., 2004. Managing Customer value. Fress Press. New York.

Gronroos, Christina, 2000. Service Management and Marketing. Managing The Moment Of Truth In Service Competition. Lexington Books. New York.

Ghozali, Imam, 2004, Analisis Multivariat, Badan Penerbit Undip, Semarang.

Gujarati, Damodar, 2005. Basic Econometris, $3^{\text {rd }}$ edition. McGraw Hill International. New York.

Hadi, Sutrisno, 2000. Analisis Butir. Ganesha. Bandung.

Hair et al., 2005. Multivariate Data Analysis Witrh Reading, $4^{\text {th }}$ edition. Prentice-Hall International. New Jersey.

Humphreys, Michael A., Williams, Michael R., 2008. Exploring The Relative effect Of Salesperson Interpersonel Process Atributes and Technical product Attributes On Customer Satisfaction, Journal Of Personal Selleling and Sales Management. Vol. XVI. No. 3. US.

Kadi, Ismail, 2000. Perilaku Mahasiswa Dalam Menabung Pada bank Persero Surabaya. Thesis. Universitas Airlangga, Surabaya.

Kerlinger, Fred N., 2000. Foundation of Behavioral Research. Third Edition. Holth. Rinehart and Winston Inc. Oregon.

Kotler, Philip, 2002. Marketing Management : Analysis, Planning, Implementation.

Control. Tenth Edition. Prentice Hall Inc. New Jersey. , 2000. Marketing Management; The Millenium Edition. Internasional

Edition. Pretince Hall Inc. New Jersey.

Kuncoro, M, 2001, Metode Riset Untuk Bisnis \& Ekonomi : Bagaimana Meneliti \& Menulis Tesis?”, Erlangga, Jakarta.

Lupiyoadi, Rambat, 2001, Manajemen Pemasaran Jasa, Penerbit Salemba Empat, Jakarta.

Marso, 2003. Analisis Kepuasan Penabung Terhadap Atribut-Atribut Bank Pemerintah (Study Kodya Tarakan). Thesis. Univ. Airlangga. Surabaya.

Moorman, Christine, Rohit Deshpande, and Gerald Zaltman. 2003. Relationship Between Providers and Users Of Market Research: The Role f Personal Trust. Marketing Science Institute. Cambrige.

Nauman, Earl. 2005. Creating Customer Value : The Path To Sustainable Competitive. Thomas Executive Press. Cincinnati-Ohio.

Parasuraman, A.,V.A Zeithaml, and L.L Berry. 2003,2008,2000 "A Conceptual Model Of Service Quality And Implication For Future Research”, Journal Of Marketing, Vol.49, P. 40 - 50.

Peter, J Paul and Olson, Jerry C., 2000. Consumer Behaviour And Marketing Strategy, Fourth Edition. Irwin. Boston. 
Ridaryanto, Petrus, 2003. Analisis Perbandingan Strategi Pemasaran Tabungan Antara Bank Pemerintah dan Bank Swasta di Surabaya. Thesis. Universitas Airlangga. Surabaya.

Shaw, Arthur V., 2008. Creates Customer Value By Leveraging The Web and Other Channels. Journal Retail Bangking Service. Vol. XX. US.

Singarimbun, Masri dan Soryan Effendi, 2002. Metode Penelitian Survei. PPSK-UGM. Jogyakarta.

Sinungan, Muchdarsyah. 2002 Manajemen Dana Bank. Rineka Cipta. Jakarta.

Statistik Perbankan RI, 2006. Ekonomi dan Keuangan. Jakarta.

Sugiyono, 2001, Statistik. Jakarta: Pustaka Binaman Pressindo.

Supranto, 2004, Statistik induktif, BPFE, Yogyakarta.

Tjiptono, Fandi. 2002, Prinsip-Prinsip Total Quality Service, Yogyakarta : Penerbit Andi.

Undang-Undang Republik Indonesia No. 10, 2008. Perubahan Undang-Undang No. 7 Tahun 2002 Tentang Perbankan. Jakarta.

Zeithaml, Valerie A.; Bitner, Mary Jo; 2006, Service Marketing, McGraw-Hill (International Editions)

\section{Copyrights}

Copyright for this article is retained by the author(s), with first publication rights granted to the journal.

This is an open-access article distributed under the terms and conditions of the Creative Commons Attribution license (http://creativecommons.org/licenses/by/4.0/). 